"Managing core university business performance in the wake of 'fees must fall' context: a legitimacy theoretical perspective"

\begin{tabular}{ll} 
AUTHORS & $\begin{array}{l}\text { Pumela Msweli } \\
\text { Timothy Hutton }\end{array}$ \\
\hline ARTICLE INFO & $\begin{array}{l}\text { Pumela Msweli and Timothy Hutton (2016). Managing core university business } \\
\text { performance in the wake of 'fees must fall' context: a legitimacy theoretical } \\
\text { perspective. Public and Municipal Finance, 5(4), 31-40. } \\
\text { doi:10.21511/pmf.05(4).2016.04 }\end{array}$ \\
\hline DOI & http://dx.doi.org/10.21511/pmf.05(4).2016.04 \\
\hline RELEASED ON & Monday, 26 December 2016 \\
\hline JOURNAL & "Public and Municipal Finance" \\
\hline FOUNDER & LLC "Consulting Publishing Company "Business Perspectives"
\end{tabular}

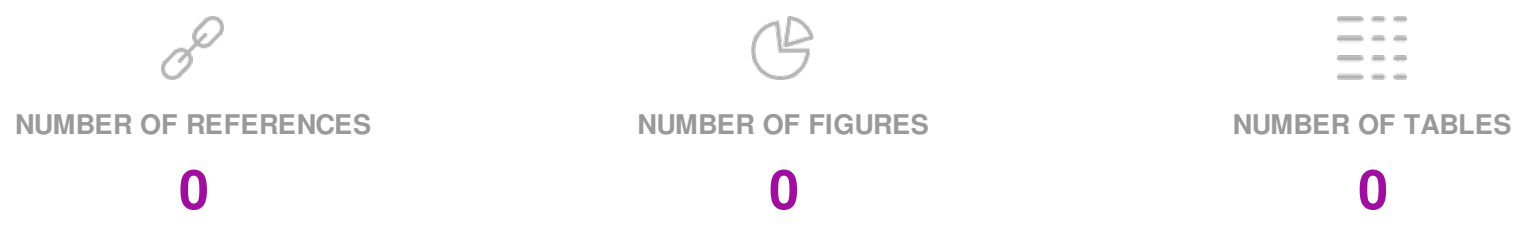

(C) The author(s) 2023. This publication is an open access article. 


\title{
Managing core university business performance in the wake of 'fees must fall' context: a legitimacy theoretical perspective
}

\begin{abstract}
This paper uses the legitimacy theory as a lens to identify the most sustainable performance model to defend and maintain the legitimacy of higher education institutions in the midst of 'fees must fall' crisis. The body of evidence presented demonstrates that universities have at least seven critical stakeholders that control resources needed for survival, growth and legitimacy. Using this evidence, this study builds a model that looks at the impact of fee income and workload on success. The model was tested using annual time series panel data for the period 2009-2013 across 23 public universities in South Africa. The model examined the effect of fee income and workload on success rate. Basing the arguments on the notion that students are a critical constituency, with a strong influence on the amount of fee income an institution may amass, the model tested the relationship between performance and fee income using success rate as a proxy for performance. The findings showed that not only is fee income a stronger predictor of success rate, but also that fee income is negatively related to success rate of students. Policy implications of the findings are discussed.
\end{abstract}

Keywords: higher education, fee income, institutional theory, performance legitimation, workload model.

JEL Classification: I23, D31, L26.

\section{Introduction}

In June 2002, the Ministry of Education published Transformation and Restructuring: A New Institutional Landscape for Higher Education, where it outlined the transformation for the South African Higher education landscape (DHET, 2002). The years 2003 to 2009 saw the institutionalization of the Transformation and Restructuring policy document, as the universities of technology and comprehensive institutions were reconfigured through mergers and restructuring (CHE, 2009). This phenomenal transformation resulted in 23 public institutions made up of 11 universities, six comprehensive universities and six universities of technology. Subsequent to 2003-2009 university merger processes, two new universities have been created - the Sol Plaatje University and the University of Mpumalanga. Most recently (2015) the University of Limpopo campuses in Polokwane and Ga-Rankuwa separated to form the Sefako Makgatho Health Sciences University in GaRankuwa, as a separate entity from the University of Limpopo. This has resulted in 26 public higher education institutions. While the higher education sector is still grappling with the consequences of the merger process, which saw University of Limpopo undoing its merger with the former Medical University of South Africa, the sector is hit by the 'fees must fall' campaign. The campaign is the boldest statement that students have made since the phenomenal student uprising that took place in June 16, 1976.

(C) Pumela Msweli, Timothy Hutton, 2016.

Pumela Msweli, Adjunct Professor, Faculty of Management Sciences, Durban University of Technology, Durban, South Africa.

Timothy Hutton, Dr., Honorary Researcher, Faculty of Engineering and the Built Environment, University of Witwatersrand, Johannesburg, South Africa.
The 'fees must fall' campaign signifies a broad shift from labor led movement protests demanding wage increases, to a massive and highly synchronized protest demanding an affordable education system. As a response to this, the government announced that there would be no student fee increase for the 2016 academic year (DHET, 2015). The Government further announced that it will allocate R1,935 billion, which will result in a shortfall of R394,7 million (HESA, 2011). Under normal circumstances, student fee income in the higher education sector in South Africa ranges between 28-38\% (HESA, 2011). A shortfall imposed by diminishing the fee income will result in further financial pressures on already cash strapped universities. Using the legitimacy theory as a lens, this paper seeks to identify the most sustainable performance framework universities can use to manage their core business performance, while ensuring that they are aligned to their strategic intent.

This paper argues that the budget shortfall is likely to be much higher if the academic workload model is out of syncronisation with institutional differentiation strategy. This argument is based on the premise that grant funding in South African universities increased from 1996 to 2008, while state funding for fulltime students saw a decline (HESA, 2011). If universities have been struggling to finance budget shortfalls before the 'fees must fall' campaign, what are the logics that explain institutional legitimacy in a system characterized by increased demands for scarce financial resources? In addressing this question, this paper first provides a critical evaluation of legitimacy theory. The paper, then, discusses institutional differentiation and workload models in the context of performance legitimation. Thereafter, the paper presents the methodological approach and findings of the study. 


\section{Legitimacy theory}

Literature identifies, amongst others, two different types of legitimacy theory: institutional legitimacy theory also referred to as institutional theory, and performance legitimacy. Institutional legitimacy or institutional theory can be viewed as a process for institutions, in particular, government institutions, togain acceptance from constituencies within which they operate. Several authors (Battilana, Leca, \& Boxenbaum, 2009; Msweli \& Mkhize, 2007; Powell \&Colyvas 2008; Ramsey \& Amenta 2010) emphasize the role powerful social actors playin influencing attitudes, interests and values of institutions. Weber (cited in Zhao and Yang, 2013, p. 12) identifies three types of legitimacy that are the basis of government power including "traditional legitimacy", based on inherited power; "charismatic legitimacy" based on unique charismatic qualities of the head of government and "legal legitimacy" based on judicial principles that bind society. Government legitimacy, according to Zhao and Yang (2013), has been challenged on the basis that it is viewed as an outcome of false consciousness, and, as explained by Ratner (2013), false consciousness is "sense-making mechanism to produce a set of interrelated misunderstandings that sustain each other". Legitimacy has, thus, been fraught with shortcomings and failures not only on the basis of the notion of false consciousness, but also on the basis of its abstractness which makes it empirically unverifiable.

Performance legitimacy theory on the other hand, offers a window of opportunity to empirically test legitimacy. Taking on board Zhao and Yang's (2013) explanation of performance legitimacy, this study defines performance legitimacy theory as an institution's right to institute a governance system and command power on the basis of its performance. This definition is built on Powell \& Colyvas's (2008) conceptualization of legitimation as a concept given meaning by multiple actors in a social environment. In explaining this point, Tilling (2004) provides a helpful approach in working with the legitimation construct. Tilling (2004) posits that legitimacy theory must examine how relevant stakeholders influence the flow of resources crucial to the organization's establishment, growth and survival. In his work, Tilling (2004) identifies four important stakeholders: (1) government; (2) the public; (3) the financial community; and (4) media controlling resources ranging from contracts, grants (in the case of government); patronage support, labor in the case of the public, and investment in the case of financial community. Media is viewed as having a pervasive influence on how each stakeholder group makes decisions.
Tilling (2004) points out that an entity may either be in a phase of establishing legitimacy, or maintaining, extending or defending it. Even though Tilling's work looks at legitimation theory as a way to "critically unpack corporate disclosures", his analytical lens can be used to look at sustainable mechanisms for measuring how university performance can be evaluated. Accordingly, we look at core business performance legitimation on the basis of the assumption that the resources each stakeholder group controls will determine the degree to which each stakeholder group can heighten or diminish performance legitimacy. Another way of looking at this assumption is to consider the extent to which an organization or entity is able to attract resources necessary for its survival (Tilling, 2004). In view of that, we consider the resources that each of the ten stakeholder groups depicted in Figure 1 control and the influence each stakeholder group has on performance legitimacy.

\section{Key university stakeholders and performance legitimacy}

Given that students are social actors that confer legitimacy of an academic enterprise, by virtue of their presence/absence, students could be categorized as a powerful constituency. Moreover, whichever angle one takes in assessing performance, be it how higher education policies have been crafted, or how universities are ranked, to how public universities are funded, students are at the center stage of an academic enterprise. As mentioned earlier, there are three categories of public higher education institutions: (1) traditional universities, (2) universities of technology, and (3) comprehensive universities. A traditional university refers to a university that has either stayed the same or has merged with another university. A university of technology is created from the merger between two technikons. Comprehensive universities, on the other hand, are created from mergers between universities and technikons. University of Venda and the University of Zululand, however, are comprehensive institutions that were not involved in mergers. The two universities were created from traditional universities to create greater access and responsiveness to their local regions (Msweli, 2012). Comprehensive institutions are expected to contribute to meeting goals identified in the National Plan, which drive the country's Human Resource Development Strategy (Ministry of Education, 2001 cited in Msweli, 2012) and these include:

- Increasing student access to career-focused programs. 
- Improving articulation between the careerfocused and academic programs in order to facilitate student mobility between different program streams.

- Expanding opportunities for research and the expansion of applied research to benefit from university research capability.

- Enhancing capacity within institutions to respond to the social and economic needs based on regional requirements.
As pointed out by Bunting and Cloete (2010) universities of technology offer basic as well as professional undergraduate and postgraduate degrees at honours, masters and doctoral levels. Universities of technology on the other hand offer vocational and career focused undergraduate diplomas and degrees with limited offerings of masters and doctoral qualifications. Comprehensive universities offer a combination of career focused diplomas and degrees as well as postgraduate qualifications.

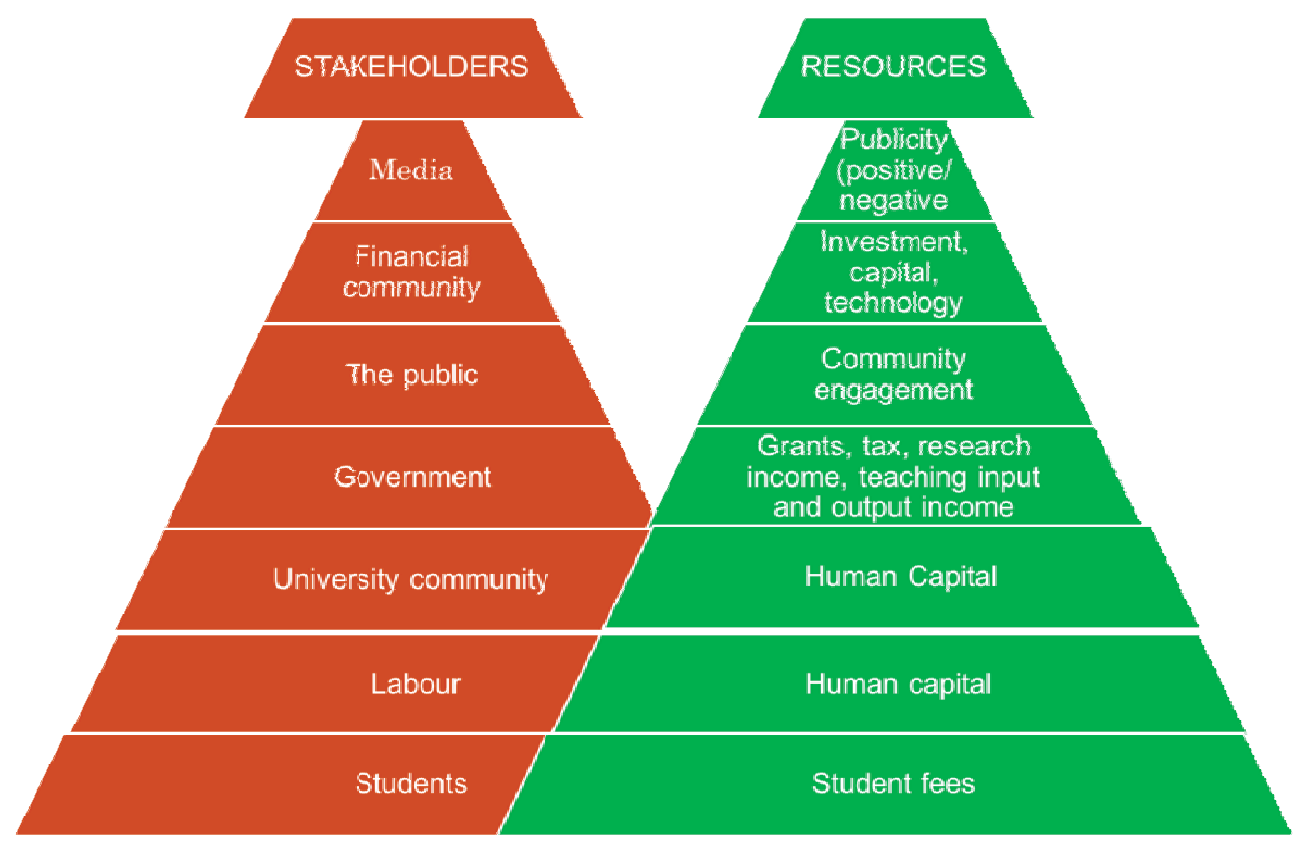

Fig. 1. Critical stakeholders in the higher education sector

Figure 1 depicts seven key university stakeholder groups that control critical resources to gain and enhance performance legitimacy. Starting from the top of the pyramid, we have media that plays a key role in influencing the flow of resources through positive publicity that communicates good will. Media could also threaten legitimacy or even lead to a loss of legitimacy, which may affect the flow of resources needed for survival. When legitimacy is threatened or lost, it may take a substantial amount of energy, time, human and financial capital to defend or re-establish it.

Next in the pyramid is the financial community, which determines the flow of capital and technology. Financial capital builds the physical, technological and research infrastructure of an academic enterprise. Without capital, it is impossible for legitimacy to be established. This particular stakeholder directly and indirectly impacts on the quality of physical assets, which, in turn, influence the institutions capacity to attract talented academics needed to heighten performance legitimacy. Highly skilled, competent and talented academics contribute substantially to performance legitimacy not only because of the human capital they bring to the university, but also because they give a university a competitive edge.
It is not possible to discuss a university's competitiveness without referring to its differentiation strategy and its workload model. There is a view that differentiation between institutions and workload models are not appropriately configured to match universities strategic focus, nor the stage in the universities development (Backhouse, 2009). In order to attempt to create differentiation for universities of technology, the South African Technology Network (SATN) has been formed. Backhouse (2009) feels that there is uneasiness amongst institutions on the issue of differentiation, as it is interpreted as a hierarchical differentiation, as opposed to being a system of differentiation based on focus areas. An observation made by Kuzilwa and Bangu (2012) is that as institutions begin to differentiate themselves and identify with their strategic focus areas, taking into account the size of the institution, allocation of workloads to staff will be done in a way that strengthens performance.

Research conducted by Kuzilwa and Bangu (2012) reveals that assistant lecturer and senior lecturer ranks have a higher teaching workload than the workload of experienced academics in the professorship rank. The effectiveness of this workload model has not been empirically tested in different university settings. There are still many unresolved puzzles and 
questions around the area of workload in academic institutions such as: would comprehensive universities require a greater cadre of senior academic staff necessary to conduct academic research as well as postgraduate supervision, or do they need emerging researchers at senior lecturer levels who are still finding their feet in building their research profile? Do universities of technology require a greater component of established faculty members to cover the bulk of the undergraduate teaching workload, or do they need faculty with limited research experience to teach undergraduate students? It is interesting to note, however, that Schejbal (2012) describes faculty members as conducting their business as artisans due to their individual skills in creating unique intellectual property. Up to now, Schejbal (2012) feels that faculty have been saved from industrialization experienced by business due to the limitations of artificial intelligence. As with other industries, the digital technology has come of age in higher education and is poised for disruptive transformation that has enveloped other sectors of the economy. This disruptive transformation comes in the form of online courses that are rapidly gaining traction in the sector resulting in significant cost savings and achievement of economies of scale, which should be taken into account in establishing and maintaining performance legitimacy.

The issue of differentiation and allocation of workload could be viewed from Callaghan's (2015) perspective. Callaghan (2015) observes that there is constant tension between teaching and research, with research being the predominant factor for academic progression. Callaghan (2015) posits that even though an academic career can follow two paths - the academic or a management path - a strong research profile determines progression. There are a number of scholars (see for example, Ewing, 2012; Kuzilwa and Bangu, 2012 that differentiate workload models for academics and academic management, suggesting flexibility in the allocation of workload, based on levels of experience and opportunities of the academic in question. Such suggestions take on board Bitzee's (2013) contention that academic activities are wideranging and time consuming. For example, the amount of time needed to plan for teaching, to deliver teaching programmes, to assess, to supervise postgraduate students to participate in community service, while simultaneously managing personal research projects and attending to academic citizenship projects is usually under estimated when implementing workload models. The assertion to "publish or perish" has transformed the manner in which academics approach workload models. Kuzilwa and Bangu (2013) are of the view that workload models are directly related to the strategy of the university. As such, if a university's performance legitimacy is achievedby a stronger research focus, the teaching focus would need to be reduced. Kuzilwa and Bangu (2013) also found that the age (maturity) of the University would influence how the workload model is designed, with less well established institutions focusing their effort on teaching and well established institutions with a heightened focus on research. Implicitly this approach is envisaged to make it possible to attract and retain more senior academics, necessary to drive the academic strategy.

This argument goes back to the differentiation strategy of the South African Higher Education Institutions. One can expect different university categories to have different staffing models, which should reflect directly in their student fees. As Figure 2 shows, government funds and student fees have increased marginally over a five year period. Private income, on the other hand, has declined by $4 \%$ over the same period. Workload models should be designed in accordance with fee income structures and revenue streams. For example, if undergraduate fee income is declining in a comprehensive university, efforts should be made to attract fee paying postgraduate students to make up for the shortfall.

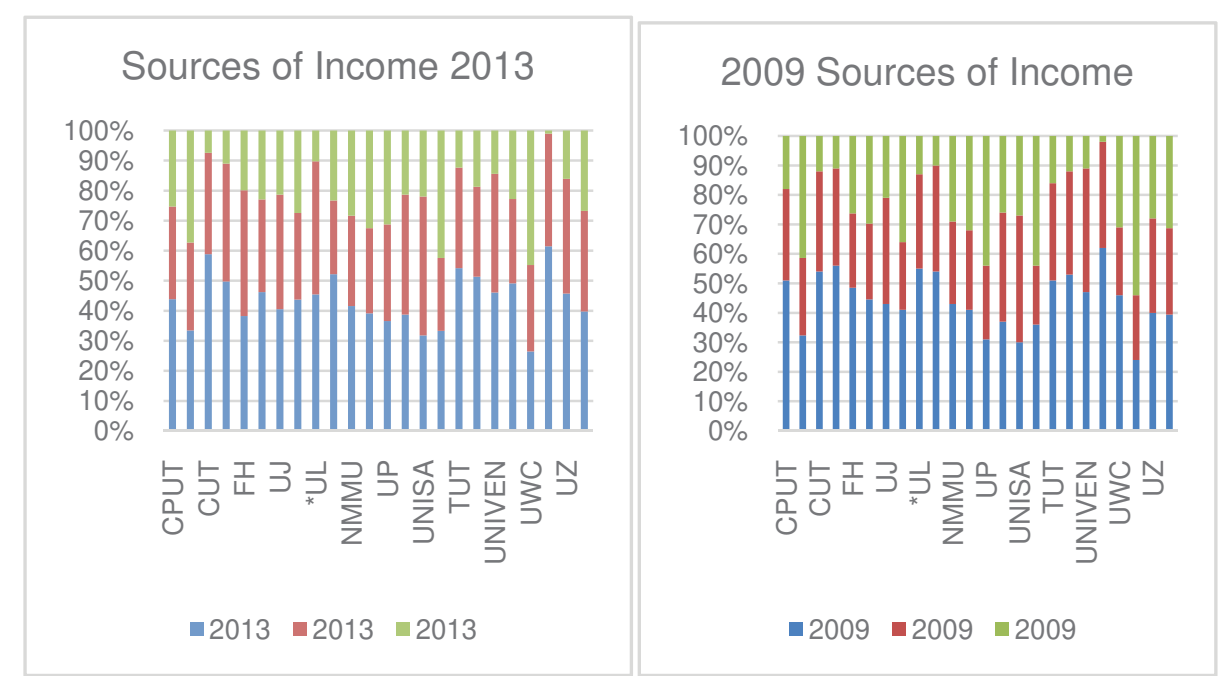

Fig. 2. Sources of income 
Judging by the performance indicators outlined in Table 1, students are a critical stakeholder in higher education. Thirteen of the 25 perfor- mance indicators (52\%) published annually by the Center for Higher Education Trust are student related.

Table 1. Higher education performance indicators 2000-2012

\begin{tabular}{|l|l|l|l|}
\hline \multicolumn{1}{|c|}{ Students } & \multicolumn{1}{|c|}{ Staff } & \multicolumn{1}{c|}{ Publications } & \multicolumn{1}{c|}{ Financial } \\
\hline 1. Enrolments & 1. No of staff & 1. Research outputs & 1. Income and expenditure \\
2. Average annual growth in head count & 2. Academic staff by rank & 2. Weighted total research & 2. Surplus/deficit on all activities \\
enrolments & output per academic staff & 3. Sources of income \\
3. No of enrolments by qualification type & 4. Academic staff by qualification & S. Research income as a \% of block \\
4. No of enrolments by major field of study & 5. Academic staff by gender & & grant \\
5. No of enrolments by race & 6. Total academic staff (FTE) & & 5. Teaching income as \% of block \\
6. No of enrolments by gender & 7. Ratio of student FTEs to staff & & grant \\
7. Success rate & FTEs & & 6. Personnel costs as \% of total \\
8. No of enrolments by qualification type & & & \\
9. No of graduates by major field of study & & & \\
10. Weighted graduates & & & \\
\hline
\end{tabular}

The importance of students as a performance legitimation resource is corroborated by the public higher education institution enrolment figures, which have increased considerably over the period between 2009 and 2015, from 425000 in 1994 to 8377779 in 2009 (CHE, 2009; CHE, 2010). According to the Council on Higher Education (2014) report, African students are still underrepresented in the total enrolments. Furthermore, the higher education system still reflects the legacy of apartheid when it comes to the profile of students who finish their degrees on time (CHE, 2016). These challenges require carefully considered interventions that take into account the decline in fee income.

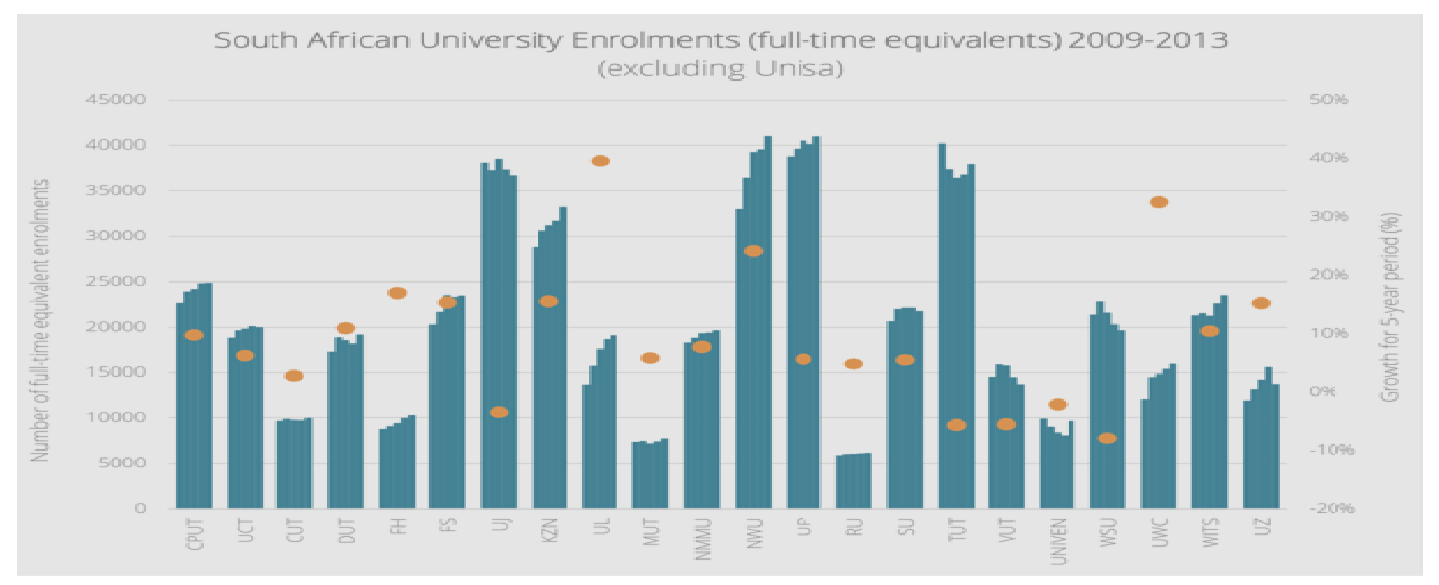

Fig. 3. South African enrolments 2009-2013

Source: CHET (2016), available at: http://chet.org.za/data/sahe-open-data.

\section{Methodology}

The study uses annual time series panel data sourced from the CHET database on South African higher education performance indicators. The empirical analysis covers the period 2009-2013 across 22 public universities in South Africa. The data have 22 panels and five periods, which amount to 110 observations. Data on three variables specified in equation 1 were sourced from the Center for Higher Education Transformation Database.

The analysis considered two major independent variables included in the base model: workload measured as the ratio of student FTEs to staff FTE and income. The dependent variable is success rate. Ordinary Least Squares Regression tested the relationships between student success income and workload. Using the panel data, modelling technique was advantageous, because it allows for capturing not only the variation of what emerges through time or space (2009-2013), but also the variation of these two dimensions simultaneously" (Podesta, 2000). Panel data analysis generates better estimations (e.g., higher T-statistics, adjusted R-square, F-statistics).

Before running the Ordinary Least Square to approximate the coefficients of the regression equation, the study tested for the stationarity of the variables. The stationarity of the time series was tested using the Augmented Dickey-Fuller (ADF) test. The Granger Causality test was used to determine the nature and direction of causality among the variables in the equations speci-fied below.

The model was specified as follows: 
Student successrate $_{\mathrm{it}}=a_{0}+a_{1} \cdot$ Income $_{\mathrm{it}}+a_{1} \cdot$ Workload $_{\mathrm{tt}} \mathrm{u}_{\mathrm{i}}+u_{t}+\mathrm{u}_{\mathrm{it}} \cdot$

\section{Findings}

Table 2 provides the descriptive statistics of the three variables in equation 1 . Success rate has a minimum of $59,7 \%$ and a maximum of $83,7 \%$. The median success rate is $77 \%$ meaning that in more than $50 \%$ of the institutions $23 \%$ and more students do not complete their studies.

Table 2. Descriptive statistics of dependent and independent variables

\begin{tabular}{|l|c|c|c|c|c|}
\hline & Mean & Median & Maximum & Minimum & Std. Dev. \\
\hline SUCCESS_RATE & 0.762668 & 0.772802 & 0.837981 & 0.597229 & 0.052455 \\
\hline WORKLOAD & 27.63352 & 26.41928 & 85.14810 & 11.35809 & 14.99492 \\
\hline INCOME & 0.306522 & 0.320000 & 0.430000 & 0.200000 & 0.063433 \\
\hline
\end{tabular}

The minimum fee income, as displayed in Table 2 , constitutes $20 \%$ of total income and the maximum income adds up to $43 \%$ of the total income. Ratio of student FTE to staff FTE is minimum of 11.3 and a maximum of 85.14.

Table 3 gives an indication of the strength and direction of the linear relationship between the three study variables.

Table 3. Correlation matrix between variables

\begin{tabular}{|l|c|c|c|}
\hline & SUCCESS_RATE & WORKLOAD & INCOME \\
\hline SUCCESS_RATE & 1.000000 & -0.738457 & -0.501900 \\
\hline WORKLOAD & -0.738457 & 1.000000 & 0.636011 \\
\hline INCOME & -0.501900 & 0.636011 & 1.000000 \\
\hline
\end{tabular}

As expected, workload shows a strong and negative relationship with the success rate. This finding implies that as workload increased success rate decreases. Success rate also correlates fairly strongly with fee income, as expectes. The relationship between success rate and fee income is negative. This finding is counter-intuitive, because one would have expected that the commitment that goes with paying fees would translate to a higher success rate.

To study the relationships specified in equation 1 , the OLS regression technique was used. The limitation of the OLS technique is that it does not discriminate between the various institutions, nor does it tell us whether the relationship between success rate, income and workload is the same for each university over time. Put differently, grouping the universities together at different times results in the model not recognizing the heterogeneity that may exist among the universities. A fixed effects model takes heterogeneity characteristics into account.

The variables included in the Ordinary Least Square (OLS) estimation may be subject to potential bias due to several reasons. One likely bias is omitted variables bias, as it is probable that some important factors omitted as explanatory variables may affect corruption, human capital and social development simultaneously. The fixed effect model can adjust for unobserved effects that are correlated with covariates. It is also possible to use a fixed effects model to account for time-invariant unobserved factors that might be correlated with the variables that are included in the regression equation. The fixed effects explore the relationship between corruption and the selected variables within each country (Baltagi 2001).

An assumption of the fixed effects model is that time-invariant characteristics (organizational culture and mission statements of universities) are unique to individual institutions. Therefore, each institutions success rate has its own unique features. Therefore error term of each institution and the constant should not be correlated with others. This way, the results are adjusted for effects that are institution specific.

The following fixed effect model is estimated:

Student success rate $_{\mathrm{it}}=\beta_{0}+\beta_{1} \cdot$ Income $_{\mathrm{it}}+\beta_{21} \cdot$ Workload $_{\mathrm{it}}+\gamma_{i}+\delta_{\mathrm{t}}+\varepsilon_{\mathrm{i}, \mathrm{t}}$,

- $\beta$ is coefficient for independent variables (workload and fee income),

- $\varepsilon_{\mathrm{i}, \mathrm{t}}-$ depicts the error term across institutions and time,
- $\gamma_{i}$ - stands for specific institution characteristics constant over time,

- $\delta_{\mathrm{t}}-$ depicts is a time-specific effect,

- $\mathrm{i}$ - institutions, $\mathrm{t}-$ time. 
Before estimating equation 2, stationarity of the data series was tested using panel unit root method to ensure that the variables used in the regressions were not subject to spurious correlation. All the variables considered, Success rate, fee income and workload, are stationary at level and need not to be differenced.

Table 4. Results of fixed effects testing

\begin{tabular}{|c|c|c|c|c|}
\hline \multicolumn{5}{|c|}{ Dependent variable: SUCCESS_RATE } \\
\hline \multicolumn{5}{|c|}{ Method: pooled EGLS (cross-section weights) } \\
\hline \multicolumn{5}{|c|}{ Date: 09/16/16. Time: $15: 39$} \\
\hline \multicolumn{5}{|l|}{ Sample: 2009-2013 } \\
\hline \multicolumn{5}{|l|}{ Included observations: 115} \\
\hline \multicolumn{5}{|l|}{ Cross-sections included: 22} \\
\hline \multicolumn{5}{|c|}{ Total pool (balanced) observations: 2530} \\
\hline \multicolumn{5}{|c|}{ Linear estimation after one-step weighting matrix } \\
\hline Variable & Coefficient & Std. Error & t-statistic & Prob. \\
\hline C & 0.998502 & 0.002060 & 484.6642 & 0.0000 \\
\hline CPUT--WORKLOAD & -0.005773 & 0.000295 & -19.57909 & 0.0000 \\
\hline CUT--WORKLOAD & -0.005773 & 0.000295 & -19.57909 & 0.0000 \\
\hline DUT--WORKLOAD & -0.005773 & 0.000295 & -19.57909 & 0.0000 \\
\hline FS--WORKLOAD & -0.005773 & 0.000295 & -19.57909 & 0.0000 \\
\hline FH--WORKLOAD & -0.005773 & 0.000295 & -19.57909 & 0.0000 \\
\hline MUT--WORKLOAD & -0.005773 & 0.000295 & -19.57909 & 0.0000 \\
\hline NMMU--WORKLOAD & -0.005773 & 0.000295 & -19.57909 & 0.0000 \\
\hline NWU--WORKLOAD & -0.005773 & 0.000295 & -19.57909 & 0.0000 \\
\hline RU--WORKLOAD & -0.005773 & 0.000295 & -19.57909 & 0.0000 \\
\hline SU--WORKLOAD & -0.005773 & 0.000295 & -19.57909 & 0.0000 \\
\hline UCT--WORKLOAD & -0.005773 & 0.000295 & -19.57909 & 0.0000 \\
\hline UJ--WORKLOAD & -0.005773 & 0.000295 & -19.57909 & 0.0000 \\
\hline UL--WORKLOAD & -0.005773 & 0.000295 & -19.57909 & 0.0000 \\
\hline UKZN--WORKLOAD & -0.005773 & 0.000295 & -19.57909 & 0.0000 \\
\hline UP--WORKLOAD & -0.005773 & 0.000295 & -19.57909 & 0.0000 \\
\hline UNISA--WORKLOAD & -0.005773 & 0.000295 & -19.57909 & 0.0000 \\
\hline UNIVEN--WORKLOAD & -0.005773 & 0.000295 & -19.57909 & 0.0000 \\
\hline UWC--WORKLOAD & -0.005773 & 0.000295 & -19.57909 & 0.0000 \\
\hline TUT--WORKLOAD & -0.005773 & 0.000295 & -19.57909 & 0.0000 \\
\hline VUT--WORKLOAD & -0.005773 & 0.000295 & -19.57909 & 0.0000 \\
\hline UZ--WORKLOAD & -0.005773 & 0.000295 & -19.57909 & 0.0000 \\
\hline WITS--WORKLOAD & -0.005773 & 0.000295 & -19.57909 & 0.0000 \\
\hline CPUT--INCOME & -0.253485 & 0.040409 & -6.272991 & 0.0000 \\
\hline CUT--INCOME & -0.253485 & 0.040409 & -6.272991 & 0.0000 \\
\hline DUT--INCOME & -0.253485 & 0.040409 & -6.272991 & 0.0000 \\
\hline FS--INCOME & -0.253485 & 0.040409 & -6.272991 & 0.0000 \\
\hline FH-INCOME & -0.253485 & 0.040409 & -6.272991 & 0.0000 \\
\hline MUT--INCOME & -0.253485 & 0.040409 & -6.272991 & 0.0000 \\
\hline NMMU--INCOME & -0.253485 & 0.040409 & -6.272991 & 0.0000 \\
\hline NWU--INCOME & -0.253485 & 0.040409 & -6.272991 & 0.0000 \\
\hline RU--INCOME & -0.253485 & 0.040409 & -6.272991 & 0.0000 \\
\hline SU--INCOME & -0.253485 & 0.040409 & -6.272991 & 0.0000 \\
\hline UCT--INCOME & -0.253485 & 0.040409 & -6.272991 & 0.0000 \\
\hline UJ--INCOME & -0.253485 & 0.040409 & -6.272991 & 0.0000 \\
\hline UL--INCOME & -0.253485 & 0.040409 & -6.272991 & 0.0000 \\
\hline UKZN--INCOME & -0.253485 & 0.040409 & -6.272991 & 0.0000 \\
\hline UP--INCOME & -0.253485 & 0.040409 & -6.272991 & 0.0000 \\
\hline UNISA--INCOME & -0.253485 & 0.040409 & -6.272991 & 0.0000 \\
\hline UNIVEN--INCOME & -0.253485 & 0.040409 & -6.272991 & 0.0000 \\
\hline UWC--INCOME & -0.253485 & 0.040409 & -6.272991 & 0.0000 \\
\hline TUT--INCOME & -0.253485 & 0.040409 & -6.272991 & 0.0000 \\
\hline VUT--INCOME & -0.253485 & 0.040409 & -6.272991 & 0.0000 \\
\hline UZ--INCOME & -0.253485 & 0.040409 & -6.272991 & 0.0000 \\
\hline WITS--INCOME & -0.253485 & 0.040409 & -6.272991 & 0.0000 \\
\hline
\end{tabular}


Table 4 (cont). Results of fixed effects testing

\begin{tabular}{|c|c|c|c|}
\hline \multicolumn{4}{|c|}{ Effects specification } \\
\hline \multicolumn{4}{|c|}{ Cross-section fixed (dummy variables) } \\
\hline \multicolumn{4}{|c|}{ Weighted statistics } \\
\hline R-squared & 0.889454 & Mean dependent var & 0.775382 \\
\hline Adjusted R-squared & 0.886537 & S.D. dependent var & 0.037440 \\
\hline S.E. of regression & 0.012611 & Sum squared resid & 0.391895 \\
\hline F-statistic & 305.0045 & Durbin-Watson stat & 2.848915 \\
\hline Prob (F-statistic) & 0.000000 & & \\
\hline \multicolumn{4}{|c|}{ Unweighted statistics } \\
\hline R-squared & 0.889454 & Mean dependent var & 0.775382 \\
\hline Sum squared resid & 0.391895 & Durbin-Watson stat & 2.848915 \\
\hline
\end{tabular}

Table 4 shows that the cross-section fixed effects for each university are all negative. This means that unobserved factors that differ from one university to the next, but do not change over time within each university have negative effects. The statistical evidence as shown by the $p$-values, is overwhelmingly in favor of keeping the fixed effects in the model. High R-squared values show model parsimony. The Durbin-Watson statistic of 2.84 shows that the reported standard errors and $t$-statistics are not far off and the null hypothesis illustrates that there is no serial correlation that is accepted.

As Table 5 shows, the intercept is estimated to be 1.02 and the strength of the relationship between success rate and income is estimated to be $\beta_{1}=-0,412$ and the strength of the relationship between workload and success $\beta_{12}=-0,004$ showing that fee income is the strongest predictor of success rate rather than workload. The high $\mathrm{R}$-squared value (0.91) means the regression fits the data.

Table 5. Panel list squares output

\begin{tabular}{|c|c|c|c|c|}
\hline \multicolumn{5}{|c|}{ Dependent variable: SUCCESS_RATE } \\
\hline \multicolumn{5}{|c|}{ Method: panel least squares } \\
\hline \multicolumn{5}{|l|}{ Date: 09/16/16 Time: 21:04 } \\
\hline \multicolumn{5}{|l|}{ Sample: 2009-2013 } \\
\hline \multicolumn{5}{|l|}{ Periods included: 5} \\
\hline \multicolumn{5}{|l|}{ Cross-sections included: 23} \\
\hline \multicolumn{5}{|c|}{ Total panel (balanced) observations: 115} \\
\hline Variable & Coefficient & Std. Error & t-statistic & Prob. \\
\hline @TREND & -0.005333 & 0.001236 & -4.315616 & 0.0000 \\
\hline $\mathrm{C}$ & 1.019841 & 0.010253 & 99.46426 & 0.0000 \\
\hline INCOME & -0.411925 & 0.052524 & -7.842667 & 0.0000 \\
\hline WORKLOAD & -0.004343 & 0.000430 & -10.10324 & 0.0000 \\
\hline R-squared & 0.905337 & \multicolumn{2}{|c|}{ Mean dependent var } & 0.775382 \\
\hline Adjusted R-squared & 0.902779 & \multicolumn{2}{|c|}{ S.D. dependent var } & 0.037597 \\
\hline S.E. of regression & 0.011723 & \multicolumn{2}{|c|}{ Akaike info criterion } & -6.020406 \\
\hline Sum squared resid & 0.015254 & \multicolumn{2}{|c|}{ Schwarz criterion } & -5.924930 \\
\hline Log likelihood & 350.1733 & \multicolumn{2}{|c|}{ Hannan-Quinn criter. } & -5.981653 \\
\hline F-statistic & 353.8602 & \multicolumn{2}{|c|}{ Durbin-Watson stat } & 3.758547 \\
\hline Prob (F-statistic) & 0.000000 & & & \\
\hline
\end{tabular}

\section{Discussion and policy recommendations}

The paper examined the effect of fee income and workload on success rate. Basing the arguments on the notion that students are a critical constituency with strong influence on the amount of fee income an institution may amass, we developed a model to test the relationship between success rate and fee income. We included workload and looked at the fixed effects of omitted variables on the dependent variable (success rate). Our findings showed that not only is fee income a stronger predictor of success rate, but that income is negatively related to success. This means that, on bal- ance, as fee income increases, the success rate decreases. This could be interpreted in two ways. Firstly, when students access an institution of higher learning, their success rate will be determined by the extent to which they can afford fees. Given the socio-economic factors of the majority of South African students, it is not unreasonable to expect the success rate to be influenced by their ability to afford fees. Another way of interpreting the findings is that there are more students in the South African higher education sector who cannot afford to pay fees than those who can afford, which explains why there is a negative relationship between fee income and success rate. 
Current education subsidies have failed to finance the cost of education for the poor. Removing the finance burden carried by poor students is likely to improve success rate. Should fees fall, as demanded by South African students, the shortfall would have to be funded differently. Policy could be crafted such that a different form of education tax is levied to employees who are recipients of higher education from publicly funded universities. Such a policy is likely to be legitimized by all social and economic actors, because it requires that students who are the legitimising force in the fees must fall campaign take responsibility of adding to education revenue when they assume employment after completing their studies. Policy should be crafted in a manner that discourages an extended stay at university. The higher education funding formula should also be crafted such that employa- bility of graduates has more weight than success rate. Currently, employability of graduates is not taken into account in the funding formula of higher education. The unintended consequences of such an approach is that universities generate a large number of graduates who are unemployed, because output grant funding rewards universities for pass rates and success rates that are delinked to job creation and possibly delinked to the skills needed by the globalized South African economy. Further research should look into the quantum of publicly funded graduates who are unemployed in relation to the input and output grant funding institutions receive. Such research will not only shed light into the cost and benefits of the current funding formula, but will identify mechanisms for strengthening the links between education output, employability and job creation.

\section{References}

1. Backhouse, J. (2009). The Place and Role of Universities of Technology in the Higher Education Sector. Presentation to the South African Technology Network (SATN) $2^{\text {nd }}$ Annual Conference Conference, 16-17 July 2009, Cape Town. Accessed 30/08/2016 at 15.45.

2. Bitzer, E.M. (2013). Attempting a Fair and Equitable Academic Workload Distribution in a Faculty of Education, Journal of Higher Education.

3. Bunting, I. and Cloete, N. (2010). Institutional Types in Higher Education in South Africa. Available at: http://www.chet.org.za/files/uploads/events/dialogues_he/Session\%202a\%20Institutional\%20Types\%20in\%20SA $\% 20 \mathrm{HE} \% 20-\% 20$ Ian\%20Bunting.pdf [accessed 05/07/2016 at 18:02].

4. Callaghan, C.W. (2015). Designation differences and academic career progression, Acta Commercii, 15 (1), Art. \#267, p. 12. http://dx.doi. org/10.4102/ac.v15i1.267.

5. Callaghan, C.W. (2016). Publish or perish: Family life and academic research productivity, SA Journal of Human Resource Management/SA TydskrifvirMenslikehulpbronbestuur, 14 (1), a727. http://dx.doi.org/10.4102/sajhrm. v14i1.727.

6. CHE. (2007). Review of Higher Education in South Africa. Pretoria. Council on Higher Education.

7. CHE. (2009). Higher Education Monitor: The State of Higher Education in South Africa. Pretoria. Council on Higher Education.

8. CHET. (2016). NEW higher education performance indicator data 2009 to 2013. Available at: http://chet.org.za/data/sahe-open-data [accessed 14/07/206 at 10:04].

9. DHET. (2002). Transformation and Restructuring: A New Institutional Landscape for Higher Education Ministry of Education. Available at: http://www.dhet.gov.za/Reports\%20Doc\%20Library/New\%20Institutional\%20landscape\%20for\%20Higher\%20E ducation\%20in\%20South\%20Africa.pdf [accessed 05/07/2016 at 16:56].

10. DHET. (2015). University Funding \& 2015 MTBPS: hearing with DHET \& Council on Higher Education, with Minister. Available at: https://pmg.org.za/committee-meeting/21785/ [accessed 05/07/2016 at 16:40].

11. Ewing. (2012). Formal academic workload allocation models: An agnostic's pragmatic perspective. LH Martin Institute. 27 March 2012. Accessed 10/09/2012 at 18:12.

12. HESA. (2011). Minutes of Higher Education and Training Meeting on Access to Higher Education: Challenges: Higher Education SA 07 February 2011. Accessed 05/07/2016 at 17:01.

13. Hutton, W. (1999). The Development of a Model of Performance Indicators Required for the Effective Management of South African Universities and Technikons, MBA Research Paper, Port Elisabeth Technikon.

14. Kuzilwa and Bangu. (2012). Challenges in Workload Allocation Models and Human Resources Management in Universities. Available at: http://www.academia.edu/15798052/Dynamics_of_Education_Policy_Reforms_in_Tanzania_The_Trend_Challen ges_and_Way_forward_Published_in_UONGOZI_Journal_of_Management_and_Development_Dynamics_vol.24 ._Issue_1_June_2013._PP._46-82 [accessed 10/09/2012 at 18:04].

15. Msweli, P. (2012). Retaining Generation X Academics in Higher Education Institutions, Annals of Management Science, 1 (1), December 2012, pp. 83-96.

16. Schejbal. (2012). In search of a New Paradigm for Higher Education. Springer Science and Business Media, LLC, Innov High Educ, 37, pp. 373-386. DOI 10.1007/s10755-012-9218-z. Available at: 
http://web3.apiu.edu/researchfile/Research\%20Materials/Current\%20Trends\%20in\%20Education/In\%20search\%2 0of\%20a\%20new\%20paradigm\%20for\%20higher\%20education.pdf. [accessed 28/08/2016 at 16:45].

Appendix. List of South African public universities used in Table 4

\begin{tabular}{|l|l|}
\hline CPUT & Cape Peninsula University of Technology \\
\hline CUT & Central University of Technology \\
\hline DUT & Durban University of Technology \\
\hline FS & Free State \\
\hline FH & Fort Hare \\
\hline MUT & Mangosuthu University of Technology \\
\hline NMMU & Nelson Mandela Metropolitan University \\
\hline NWU & North West University \\
\hline RU & Rhodes University \\
\hline SU & Stellenbosch University \\
\hline UCT & University of Cape Town \\
\hline UJ & University of Johannesburg \\
\hline UL & University of Limpopo \\
\hline UKZN & University of KwaZulu-Natal \\
\hline UP & University of Pretoria \\
\hline UNISA & University of South Africa \\
\hline UNIVEN & University of Venda \\
\hline UWC & University of the Western Cape \\
\hline TUT & Tshwane University of Technology \\
\hline VUT & Vaal University of Technology \\
\hline UZ & University of Zululand \\
\hline WITS & University of the Witwatersrand \\
\hline & \\
\hline
\end{tabular}

